\title{
特集 最新の画像診断法
}

\section{0 列面検出器 CT（320 row Area Detector CT [320r AD-CT]）の 脳神経外科領域への応用}

\author{
早川基治*1 村山和宏*2 片田和 廣*2 廣 瀬 雄一*1
}

\author{
Usefulness of 320-Row Area Detector CT in Neurosurgery \\ by
Motoharu Hayakawa, M.D. ${ }^{* 1}$, Kazuhiro Murayama, M.D. ${ }^{* 2}$, Kazuhiro Katada, M.D. ${ }^{* 2}$, and Yuichi Hirose, M.D. ${ }^{* 1}$

from

${ }^{*}$ Department of Neurosurgery, Fujita Health University

${ }^{* 2}$ Department of Radiology, Fujita Health University

The introduction of 320-row area detector CT (ADCT) has led to a new era in CT. ADCT should not be thought of as conventional CT scanning with a larger number of detector rows. Since the overall width of the detector is greatly expanded, the brain can be scanned in a single rotation. This makes it possible to perform non-contrast CT scanning in a single rotation. ADCT also permits volume data to be acquired along the temporal axis by continuous scanning (4D data).

Since scanning can be completed in a single rotation, sedation is not required even in patients who may be difficult to examine, such as pediatric patients and patients with impaired consciousness. Scanning can also be completed in approximately 1 second in routine 3D-CTA studies, permitting the amount of contrast medium to be reduced. In addition, volume data from the arterial phase to the venous phase ( $4 \mathrm{D}$ data) can be acquired by sequential scanning (continuous or intermittent scanning). In particular, since ADCT is superior to DSA in terms of tissue contrast, especially in the venous phase, visualization is improved and three-dimensional assessment can be performed more easily. In addition, ECG-gated continuous volume scanning allows an extensive range from the head through the carotid arteries to the heart (coronary arteries) to be examined in a single scan. Given the strong association between carotid artery stenosis and coronary artery stenosis, the ability to assess both in a single study is of great clinical value. ADC'T also supports 160 -row helical scanning, which permits the range from the head to the inguinal region to be scanned in approximately 6 seconds. Moreover, since ADCT allows the arteries of the entire body to be examined with no increase in the amount of contrast medium, the range from the location where the sheath is to be introduced to the lesion can be confirmed before neuroendovascular therapy.

As discussed above, ADCT has many advantages. However, ADCT studies can generate a huge number of reconstructed images, sometimes reaching several thousand. It is impossible to interpret all of these images individually. In addition, sequential scanning is associated with higher $\mathrm{X}$-ray exposure. It is therefore essential to select the ideal scanning method for the clinical objective, to set the optimal exposure dose, and to perform reconstruction and analysis appropriately.

(Received December 29, 2010; accepted January 19, 2011)

Key words : cerebral aneurysm, 3D-CTA, ECG gated, brain tumor, cerebral infarction

Jpn J Neurosurg（Tokyo） $20: 640-647,2011$

\footnotetext{
*1藤田保健衛生大学医学部脳神経外科 $/ \bar{T} 470-1192$ 豊明市沓掛町田楽ヶ社 1-98〔連絡先：早川基治〕

Address reprint requests to: Motoharu Hayakawa, M.D., Department of Neurosurgery, Fujita Health University, 1-98 Dengakugakubo, Kutsukake-cho, Toyoake-shi, Aichi 470-1192, Japan

$* 2$ 同放射線科 


\section{はじめに}

Computed tomography（CT）は，1973 年に Hunsfield GN らによって開発されて以来, 現在も脳神経外科領域 では最も多く使用される検査機器の一つである. 開発当 初は 1 スライスずつ撮影を行っていたが, 1989 年のへリ カル CT の登場により, 2 次元から volume data の概念が 一気に確立し, 3 次元画像が身近なものになった。当初 は頭蓋底部を中心とした狭い範囲の 3D-CT angiography (3D-CTA) が行われ，主に脳動脈瘤の診断に応用された。 1999 年より 4 列の Multi Detector CT (MD-CT) が開発 され，瞬く間に 64 列まで拡大し，その検査範囲は全身 を細かなスライスで一度にスキャンできるまでに広がつ た。
320 row Area Detector CT (320r AD-CT) は 2007 年 10 月に保険認可され, 当院へ導入された (Aquilion ONE, 東芝メディカルシステムズ, 東京) $\mathrm{AD}-\mathrm{CT}$ は MD-CT の行き着く先であるが，単に検出器の列が増えただけで なく，そのコンセプトはまったく異なっており，多くの 優れた点を有している，検査時間の短縮，画質の向上， 被曝の低減, サブトラクション機能の向上, Dynamic 3D （4D）などが挙げられる。特に，脳神経領域では 1 回の 検査で単純 CT, 造影 CT, Dynamic 3D-CTA, 全脳の perfusion image など, すべての種類の画像デー夕の取得が 可能となった。 また 160 row MD-CT としても使用可能 となり, 高分解能/広範囲のヘルカルスキャンが短時間で 可能となった。

本稿では $320 \mathrm{r} \mathrm{AD}-\mathrm{CT}$ の検査機器としての特徵と実

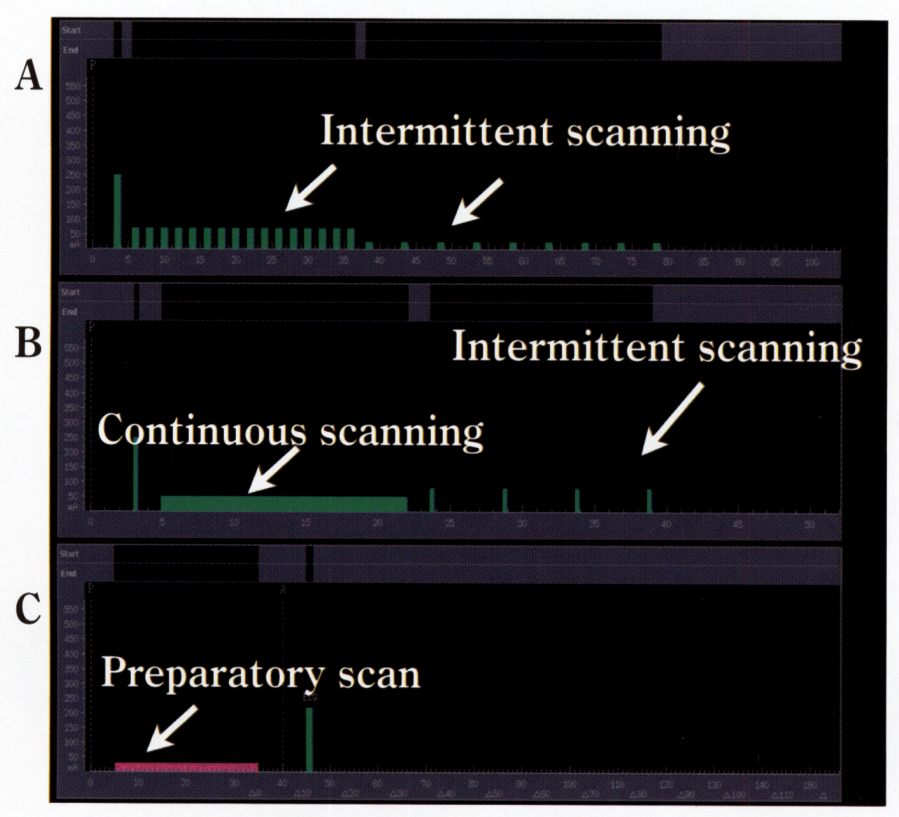

Fig. 1 Scan sequences

The vertical axis of these graphs shows the tube current and the horizontal axis shows time. The green bars indicate planned scans and the purple bar indicates the preparatory scan.

A : Scan sequence for CTP in cerebral infarction or for assessment of brain tumors. This sequence consists of intermittent scans only. At the beginning of the examination, the tube current is high in order to acquire non-contrast CT images (used for diagnosis and subtraction). After that, intermittent scanning is performed. In the second half of the examination, intermittent scanning is performed with a lower tube current at longer intervals in order to minimize the exposure dose.

B : Scan sequence for AVMs. This sequence consists of a combination of continuous and intermittent scanning. A test injection is performed before actual scanning, and the optimal timing for continuous scanning is determined for the scan sequence. At the beginning of the examination, the tube current is high in order to acquire non-contrast CT images (used for subtraction). Because high temporal resolution is essential when evaluating an AVM, continuous scanning is performed. However, since continuous scanning is associated with a higher exposure dose, the tube current is reduced and the scan time is shortened as far as possible. In the second half of the examination, intermittent scanning is performed to minimized the exposure dose.

$\mathrm{C}$ : Scan sequence for ECG-gated reconstruction. This sequence consists of a preparatory scan and ECGgated scanning. Scanning is performed while acquiring ECG data, and scanning is started at the optimal timing by confirming that the contrast medium has reached the head in the preparatory scan. The patient is scanned in a single cardiac cycle and the actual scan time is approximately 1 second. 


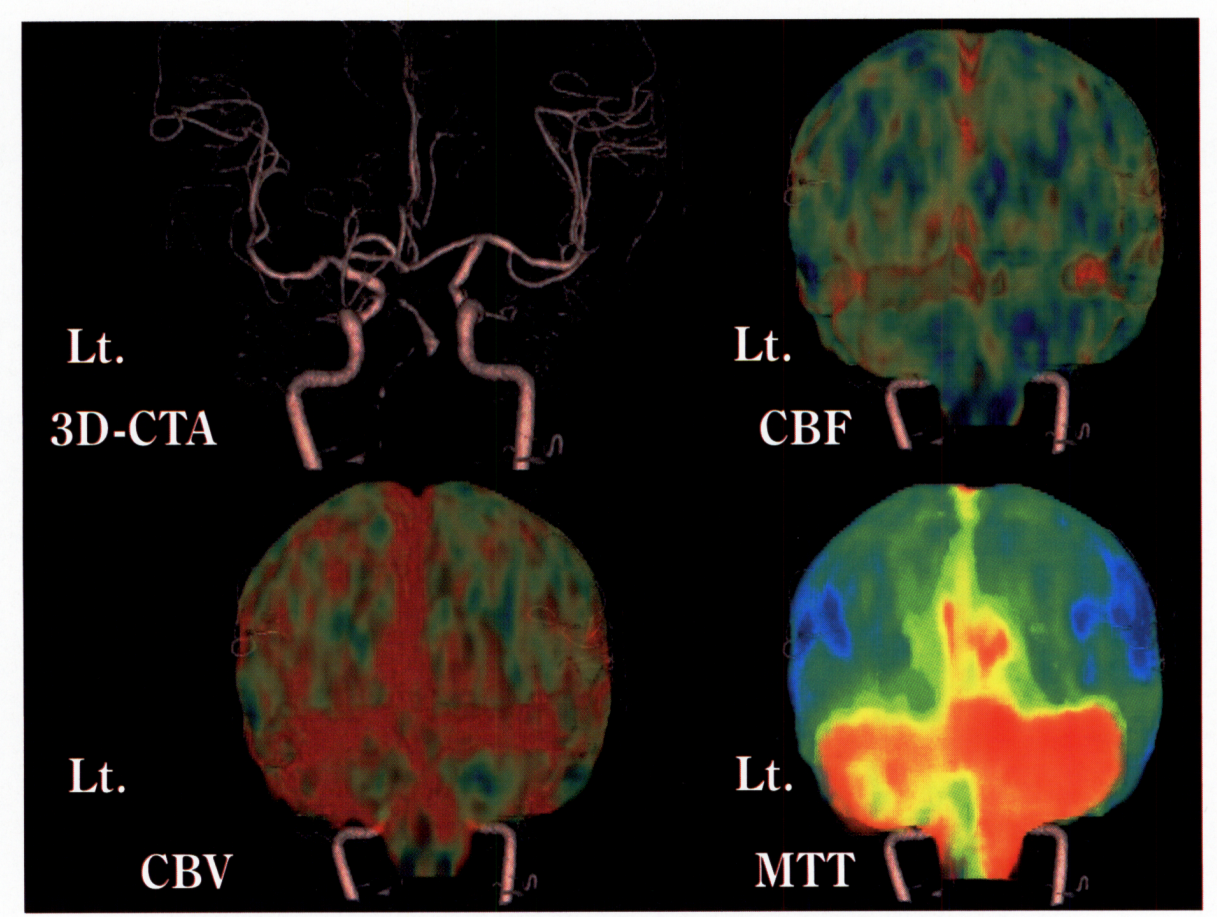

Fig. 2 Whole-brain CT perfusion: Intermittent scanning

3D-CTA: Occlusion of the right vertebral artery and basilar tip is observed. The left posterior cerebral artery is visualized arising from the left posterior communicating artery.

$\mathrm{CBF}: \mathrm{A}$ reduction in $\mathrm{CBF}$ is seen in the posterior cranial fossa to the right posterior cerebral artery.

$\mathrm{CBV}$ : A significant reduction in $\mathrm{CBV}$ is not seen.

MTT: A significant reduction in MTT is seen in the posterior cranial fossa to the right posterior cerebral artery.

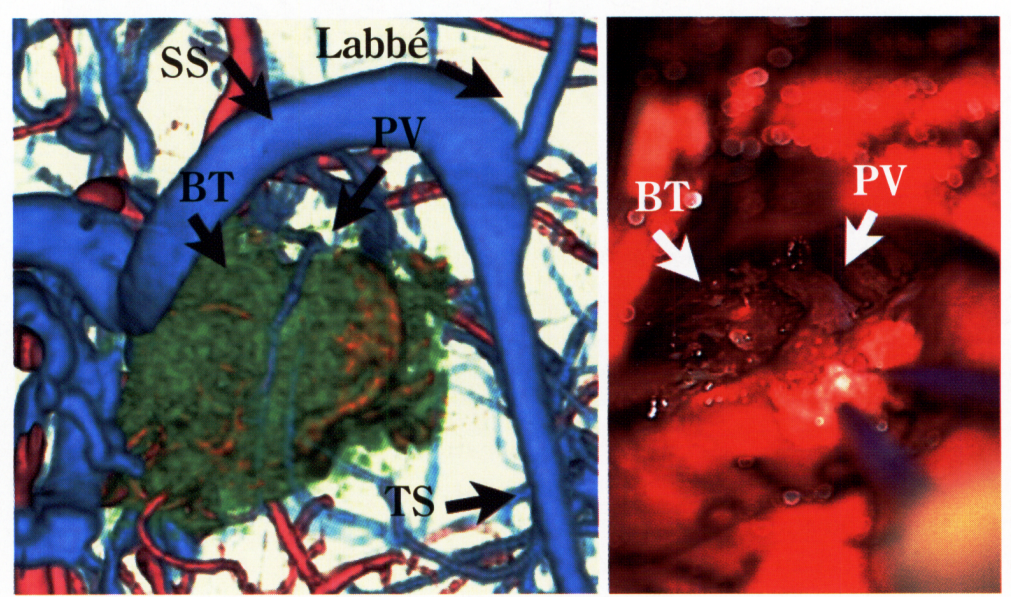

$\mathbf{A} \mid \mathbf{B}$

Fig. 3 Tumor at the left cerebellopontine angle: Intermittent scanning

A : Fusion image created by combining images acquired in the arterial phase, venous phase, and equilibrium phase.

This image shows good agreement with the intraoperative photograph.

B : Intraoperative photograph.

BT : brain tumor, Labbé : vein of Labbé, PV : petrosal vein, SS : sigmoid sinus, TS : transverse sinus

際の検査 (単純 CT, 3D-CTA, シーケンシャルスキャン

[連続撮影や間欠撮影など], 連続ボリュームスキャン, 160 列ヘリカルスキャン）について当院での経験を交え ながら紹介する2)〜4)9)11).

\section{$\mathrm{AD}-\mathrm{CT}$ の特徵}

$320 \mathrm{r} \mathrm{AD}-\mathrm{CT}$ は単に $64 \mathrm{r} \mathrm{MD}-\mathrm{CT}$ の検出器が 5 列並 んだ CTではない. 検出器そのものの新たな開発, 検出 器の幅が大きくなったことによる新たな画像再構成アル 


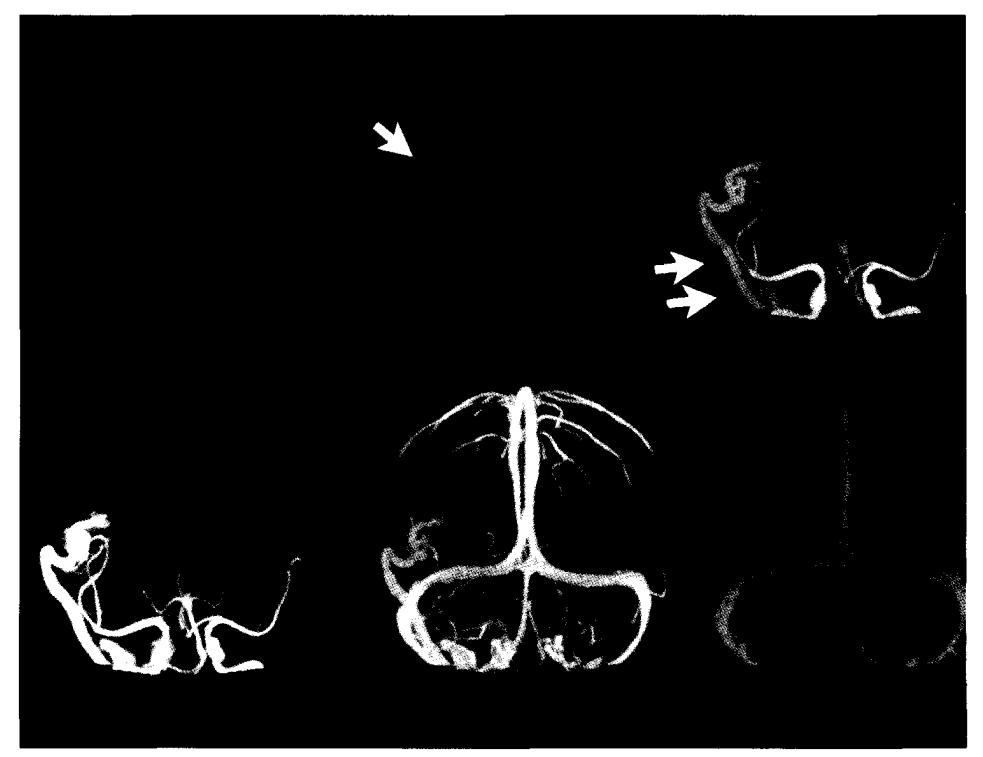

Fig. 4 Arteriovenous malformation in the right temporal lobe: Continuous scanning+ intermittent scanning

The nidus (arrow) in the right temporal lobe is visualized in the early-enhancement arterial phase.

The drainer (double arrows) is then visualized.

ゴリズムの開発が必要であった。 また，大きな管球と検 出器を高速で回転させるための躯体, 大量に発生する画 像データの転送, 保存システムの開発も同時に必要で あった。

ヘリカル CT の通常の撮影では, ある程度へリカルの 軌道は重ねながら撮影される。このため, 撮影が重なつ ている部分では必然的に被曝は倍になっている。しかし， $\mathrm{AD}-\mathrm{CT}$ では 1 回転のコンベンショナルスキャンで撮影 されるため, 撮影部分の重なりがない。このため被曝低 減が可能である，また，撮影中に寝台が移動しないため, 画質も向上している7710).

\section{1 頭部単純 CT}

$\mathrm{AD}-\mathrm{CT}$ では 1 回転で頭部全体を十分にカバーするこ とが可能である。したがって, 管球回転速度自体が撮影 時間となる。管球回転速度は最大で $0.35 \mathrm{sec} / \mathrm{r}$ であるた め, 撮影時間は最短で 0.35 秒となる。このことは小児や 意識障害患者など, 検查に協力が得られない例では鎮静 なしに検査が可能であることを示している。 また，得ら れたデータはボリュームデータであるため, 頭部が傾い ていてもワークステーション上で補正が可能である.

\section{2 造影 CT (3D-CTA)}

ヘリカルスキャンでは厳密には撮影開始位置と終了位 置では時間差があるため, 時相がずれる.しかし $\mathrm{AD}-\mathrm{CT}$ での撮影では 1 回転で撮影が可能であるため同じ時相
での撮影が可能となった。

また, 今までの CT と同様に造影剤が撮影範囲内に流 入したのを確認してから撮影するボーラストラッキング が使用できる，ただし，1回転で撮影が終了してしまう ため, 今までの CT のタイミングで撮影開始を行うと動 脈相の撮影は早すぎるので, 当施設では 5 秒間の delay timeを置き調節している.

$\mathrm{AD}-\mathrm{CT}$ ではコンベンショナルスキャンであるため, 事前に同じ部位の単純撮影を行うことにより良好なサブ トラクション画像を作ることが可能である.

\section{3 シーケンシャルスキャン}

あらかじめプログラムしておいた連続スキャン, 間欠 スキャンもしくは両者の組み合わせによる AD-CT なら ではの検査である. 単純 CT, 造影 CT, Dynamic 3D-CTA (4D-CTA), 全脳 CT Perfusion（CTP）など，すべての 種類の画像デー夕を 1 度の検査で取得可能である。しか し, 多数回のスキャンにより被曝は増大するため, 検査 目的に合わせた最適化が必要である（Fig. 1A，B）。

\section{1. 脳虚血, 䑈腫瘍 (Fig. 2, 3)}

造影 5 秒後より間欠スキャンを 60 ～ 80 秒間行うこと により，全脳の CTP を行うことが可能である.リアル タイム再構成を併用することにより, 後半部分の撮影で は必要なしと判断できれば検査を終了し画像の解析に移 ることも可能である。これは撮影の回数を減らすことに より被曝低減に役立つ。 また，同じデータより造影前の 

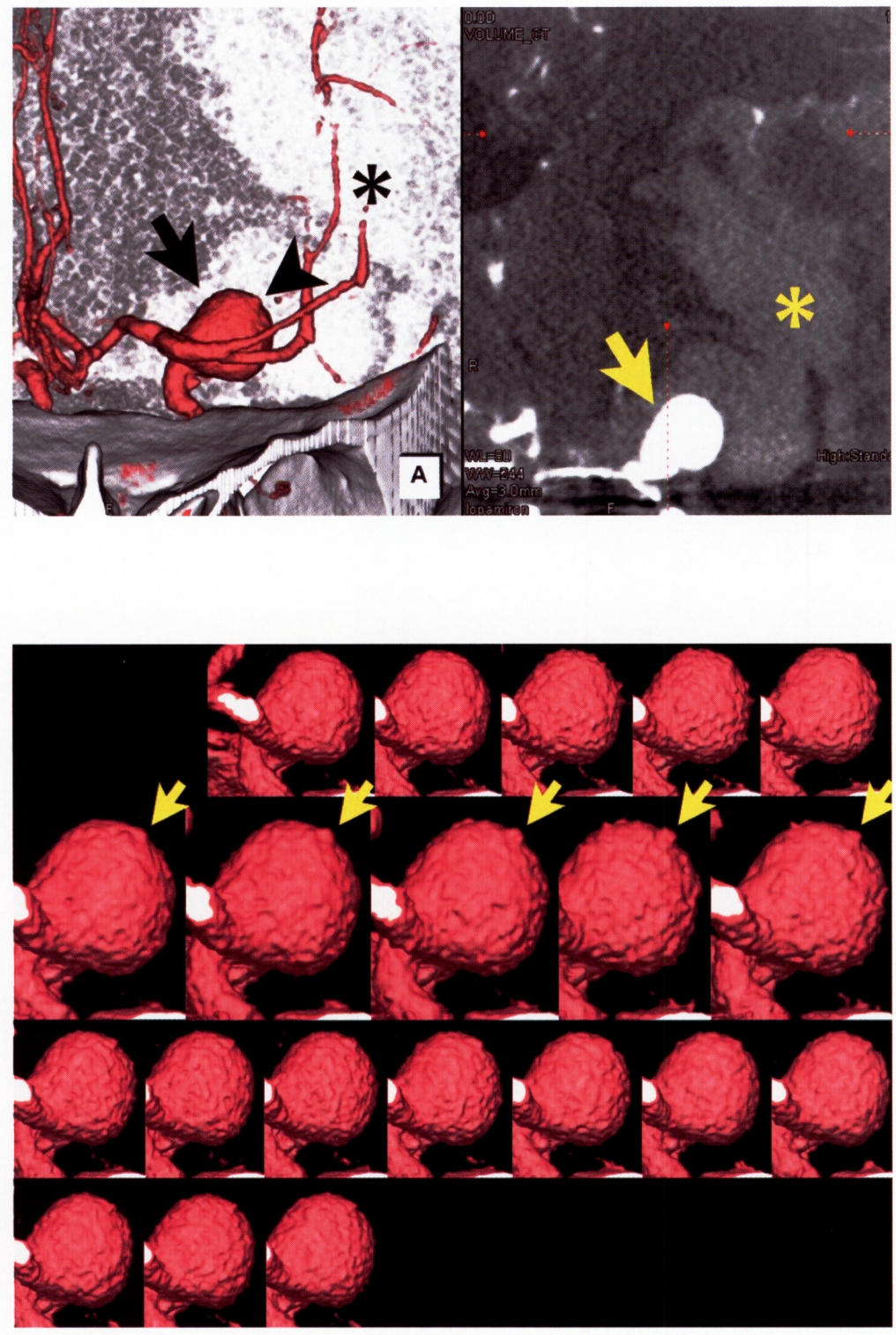

Fig. 5 3D-CTA of a large ruptured aneurysm of the left ICA

A large aneurysm (arrow) is seen in the left internal carotid artery. A small bleb (arrowhead) is seen in the dome of the aneurysm, with a hematoma $(*)$ associated with the bleb.

(Reprint with permission from Ref. 4 and Ref. 6)
Fig. 6 ECG-gated CTA of a large ruptured aneurysm of the left ICA

In this ECG-gated CTA study, a single cardiac cycle was divided into 20 phases. In the 6 th to 10 th of the 20 phases, an elevation in the dome of the aneurysm is observed. Based on the distribution of the hematoma, this elevation can be identified as the bleeding site. (Reprint with permission from Ref. 4 and Ref. 6)
画像データを用い，単純 CT の再構成することが可能で ある。造影早期の画像デー夕を用い, 動脈相の 3D-CTA を再構成することが可能である。 また, 造影後期の画像 デー夕を用い静脈相の 3D-CTA の再構成が可能である. 脳腫瘍では腫瘍の造影効果を高めるため, 脳虚血の検査 よりも造影剂の使用量を増やしている.

\section{2. 脳動静脈奇形 (AVM), 頚動脈海綿静脈洞瘻 (CCF)}

(Fig. 4)

これらの疾患では高い時間分解能が必要である。 あら かじめ造影剤のテストインジェクションを行い, 造影さ れるタイミングを調べる。本番の撮影では造影される少 し前より高速 $(0.35 \mathrm{sec} / \mathrm{r})$ の連続スキャンを行う. 後半 は被曝へらすため間欠スキャンにしている.

通常の DSA と比較し, 時間分解能, 空間分解能は及 ばない.しかし, 4D-CTA ではすべての画像データは 3D
であるため，後から画像ワークステーションを用い，任 意の方向より関心領域を抜き取り，任意の時相で観察す ることが可能である。このため, 複雑な血管構造を理解 しやすくすることが可能である.

また，CT はDSA と比較し組織コントラストが優れて いるため, 静脈相ではむしろ DSA よりわかりやすいこ とがある.また動脈相, 静脈相や造影された腫瘍とフュー ジョンすることにより, それぞれの位置関係は把握しや すくなり手術のシミュレーションに有用である.

\section{3. 脳動脈瘤の心電同期再構成による拍動の検出}

(Fig. 5, 6)

もともと心電同期再構成は冠動脈の撮影に用いられて いる手法である。当院ではへリカル CT の頃より破裂脳 動脈瘤に対して心電同期再構成を行い, 破裂脳動脈瘤の 破裂部位の特定に用いていたが十分な精度がでなかっ 




Fig. 7 Scan plan for ECG-gated continuous volume scanning

The range from the head to the chest is divided into four volumes for scanning.

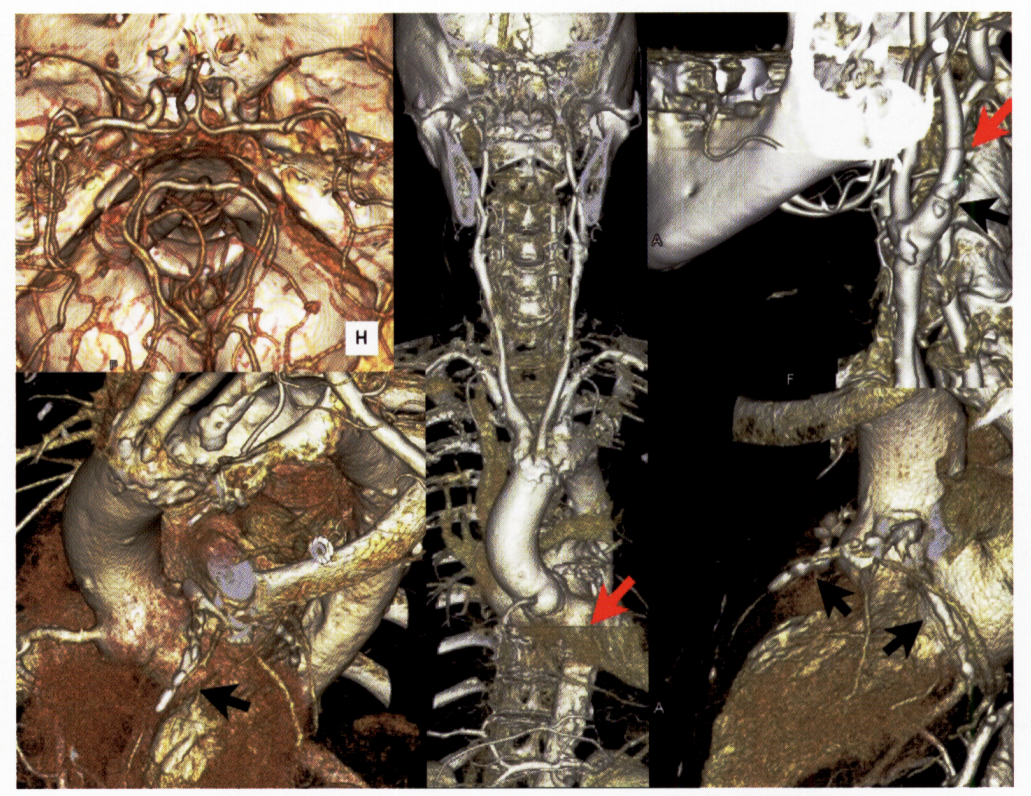

Fig. 8 ECG-gated continuous volume scanning of the range from the head to the chest

Scanning can be performed while maintaining high spatial resolution. Slight discontinuities are seen at the margins of the volume scans (red arrows in the images at the upper right and lower center).

Upper left: Details of the cerebral arteries are clearly visualized.

Upper right: Stenosis associated with calcification is seen in the left carotid artery (black arrow).

Lower left and lower right: Severe calcification is seen in the left anterior descending branch and circumflex branch(black arrows). 


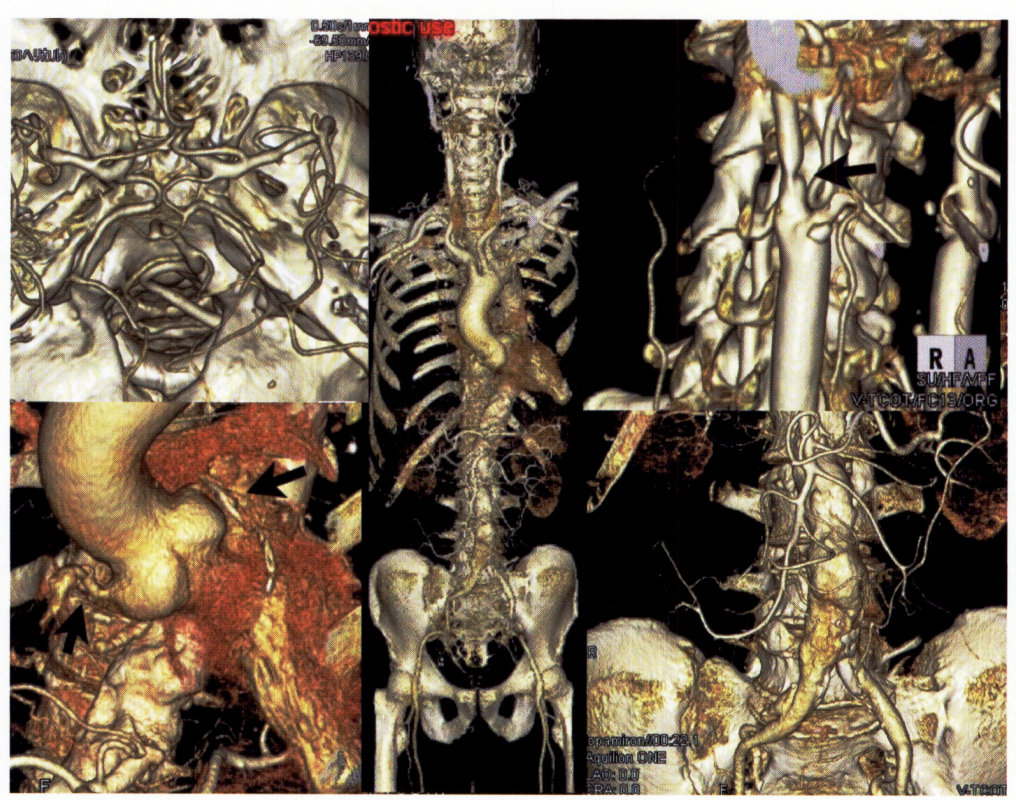

Fig. 9 3D-CTA with 160-row helical scanning of the range from the head to the inguinal region

Center: The arterial phase is clearly visualized over the entire range from the head to the inguinal region.

Upper left: Details of the cerebral arteries are clearly visualized.

Upper right: Stenosis is seen at the origin of the right internal carotid artery (arrow).

Lower left: Parts of the coronary arteries can be visualized at the optimal scan timing (arrow).

Lower right: It is important to visualize the vascular anatomy from the iliac arteries to the descending aorta, which is the access route for neuroendovascular therapy.

た. $\mathrm{AD}-\mathrm{CT}$ によりヘリカルスキャンからコンベンショ ナルスキャンに変わったことで撮影の精度は非常に向上 し, 破裂脳動脈瘤の拍動の検出と破裂部位の診断が飛躍 的に向上した 1)516)8). 撮影方法は通常の 3D-CTA を心電 情報収集下で行うものである（Fig. 1C）。

\section{4 心電同期下連続ボリュームスキャン (Fig. 7, 8)} 頚動脈狭窄症や冠動脈狭窄症は一定の確率で病変が併 発していることはよく知られている12). 通常は頭部〜頝 部までの 3D-CTA と心電同期再構成が必要な冠動脈の 3D-CTA は同時にできる検査ではない。しかし，心電同 期下連続ボリュームスキャンではボリュームスキャンの 境目に多少の段差はできるが，頭部〜心臓まで 1 度に心 電同期下で撮影が可能である.

\section{0 列ヘリカルスキャン (Fig. 9)}

160 列ヘリカルスキャンモードを使用すれば頭部から 恥骨まで 6 秒程度で撮影が可能である。当院では $50 \mathrm{ml}$ の造影剤＋後押しの生理食塩水で頭部から恥骨までの
3D-CTA が可能となった。 すなわち, 脳血管内治療前に 検査を行えば，単径部の穿刺部分から病変部までのアプ ローチの検討が可能となる。撮影の夕イミングが合えば 時に冠動脈の一部評価も可能なことがある.

\section{おわりに}

$\mathrm{AD}-\mathrm{CT}$ は単に検出器が増えた CTではなく, それに 伴いさまざまな検査が可能となった。これは単に CT だ けの進歩ではなく，検査により発生した膨大なデー夕の 転送, 保存, 再構成ワークステーションの高速化も必要 であった。そして，数千スライスに及ぶ撮影結果は，も はや 1 枚 1 枚読影することは不可能である。したがっ て, 検査目的に適した撮影方法の選択, 適切な照射線量, 適切な再構成や解析も重要である。 


\section{文 献}

1) Hayakawa M, Katada K, Anno H, Imizu S, Hayashi J, Irie K, Negoro M, Kato Y, Kanno T, Sano H: CT angiography with electrocardiographically gated reconstruction for visualizing pulsation of intracranial aneurysms: Identification of aneurysmal protuberance presumably associated with wall thinning. AJNR Am J Neuroradiol 26:1366-1369, 2005.

2）早川基治, 片田和廣, 神野哲夫, 佐野公俊：頭部領域で の 64 列マルチスライスヘリカル CT (64row MSCT) と次 世代 CT の 256 面検出器 CT (256row area detecor CT)の 使用経験。映像情報 Medical 38：92-97， 2006.

3）早川基治，佐野公俊，片田和廣，村山和宏：256 列 $/ 320$ 列 面検出器 CT (ADCT). Annual Review 2009, pp.51-57.

4）早川基治, 村山和宏, 片田和廣, 佐野公俊: 320 列 Area Detector CT の脳血管障害への応用. 分子脳血管病 9 : $15-21,2010$.

5）早川基治，根来 眞，定藤章代，入江恵子，大村真弘, 田中鉄兵, 片田和廣, 村山和宏, 平松久弥, 加藤庸子, 佐野公俊：320 列面検出器 CT (320row area detector CT (320rADCT)）の心電同期再構成による脳動脈熘拍動の 検出. CI 研究 31:247-253, 2009.

6) Hayakawa M, Maeda S, Sadato A, Tanaka T, Kaito T, Hattori N, Ganaha T, Moriya S, Katada K, Murayama K, Kato Y, Hirose Y: Detection of pulsation in ruptured and unruptured cerebral aneurysms by ECG-gated 3D-CT angiography $(4 \mathrm{D}-\mathrm{CTA})$ with 320 -row area detector CT
(ADCT) and evaluation of its clinical usefulness. Neurosugery 2011, May 26 〔Epub ahead of print].

7）片田和廣：256 面検出器 CT の技術と臨床．映像情報 Medical 38:70-79, 2006.

8) Motoyama S, Anno H, Sarai M, Sato T, Sanda Y, Ozaki Y, Mochizuki T, Katada K, Hishida $H$ : Noninvasive coronary angiography with a prototype 256-row area detector computed tomography system comparison with conventional invasive coronary angiography. $J$ Am Coll Cardiol 51: 773-774, 2008.

9) Murayama K, Katada K, Makane M, Toyama H, Anno H, Hayakawa M, Ruiz DS, Murphy KJ: Whole-brain perfusion CT performed with a prototype 256 -detector row CT system: Initial experience. Radiology 250:202-211, 2009.

10）村山和宏，中根正人，早川基治，片田和廣：320 列 area detector CT による脳血管障害の新しい画像診断. 分子脳 血管病 7:305-311, 2008.

11）村山和宏，中根正人，三田祥宏，安野泰史，外山宏，早 川基治, 片田和廣：頭部領域における 256 面検出器 CT の初期経験一ダイナミックボリュームデータの応用一. 臨床放射線 53:573-581, 2008.

12) Touzé E, Warlow CP, Rothwell PM : Risk of coronary and other nonstroke vascular death in relation to the presence and extent of atherosclerotic disease at the carotid bifurcation. Stroke 37 : 2904-2909, 2006.

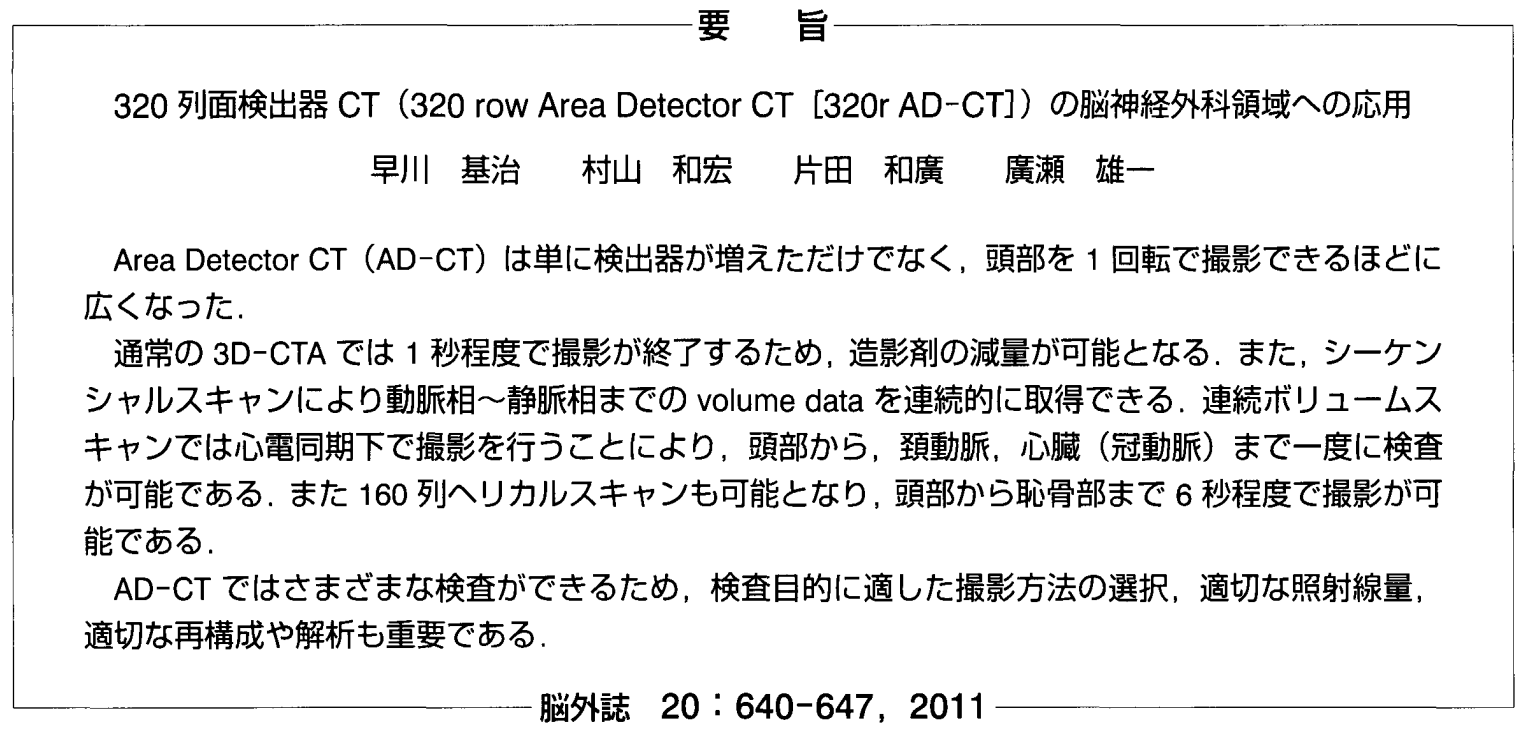

